\title{
Integrated Proactive Drought Management in Hydrosystems and 2 Cities: Building a Nine-Step Participatory Planning Methodology
}

\section{Francisco de Assis Souza Filho ( $\square$ assis@ufc.br )}

Federal University of Ceara: Universidade Federal do Ceara https://orcid.org/0000-0001-5989-1731

Ticiana Marinho de Carvalho Studart

Federal University of Ceara: Universidade Federal do Ceara

Joao Dehon Pontes Filho

Federal University of Ceara: Universidade Federal do Ceara

\section{Eduardo Sávio Passos Rodrigues Martins}

FUNCEME: Reseach Instituto of Meteorology and Water Resources

\section{Sérgio Rodrigues Ayrimoraes}

ANA: Brazil National Water Agency

\section{Carlos Alberto Perdigão Pessoa}

ANA: Brazil National Water Agency

\section{Larissa Zaira Rafael Rolim}

Federal University of Ceara: Universidade Federal do Ceara

Luiz Martins de Araújo Junior

UNILAB: Universidade da Integracao Internacional da Lusofonia Afro-Brasileira

Taís Maria Nunes Carvalho

Federal University of Ceara: Universidade Federal do Ceara

\section{Sandra Helena Silva de Aquino}

Federal University of Ceara: Universidade Federal do Ceara

\section{Research Article}

Keywords: Drought, Drought preparedness, Participatory planning, Proactive drought plan

Posted Date: May 10th, 2021

DOI: https://doi.org/10.21203/rs.3.rs-451869/v1

License: (c) (1) This work is licensed under a Creative Commons Attribution 4.0 International License.

Read Full License 


\section{Abstract}

Drought is widely known as a complex natural hazard, not just by its climatological features but also by human experiences and socio-economical impacts. Drought preparedness is the only way a society can mitigate effects and better cope with droughts. Here we present a methodological approach to guide the implementation of proactive drought plans, specially designed for hydrossystems and cities scales. We highlight strategies to engage local stakeholders in constructing such plans and build a participatory methodology. The preparedness drought plan methodology was developed and applied to two hydrosystems and two cities located in the Piranhas-Açu river basin, a drought-prone area of Brazilian Semi-arid. Our findings suggest that participatory socio-technical methodologies, built only from the system operators' tacit knowledge, can achieve good results when data and resources are limited. Still, results can be enhanced by hydrologic and hydraulic modeling to assess vulnerability, scenarios and strategies. We illustrate and analyze the process by storytelling to develop a meaningful and convincing narrative that speaks to theory and practice, and we provide recommendations to facilitate this approach.

\section{Full Text}

This preprint is available for download as a PDF.

\section{Figures}

\section{DROUGHT PLAN SCALES}

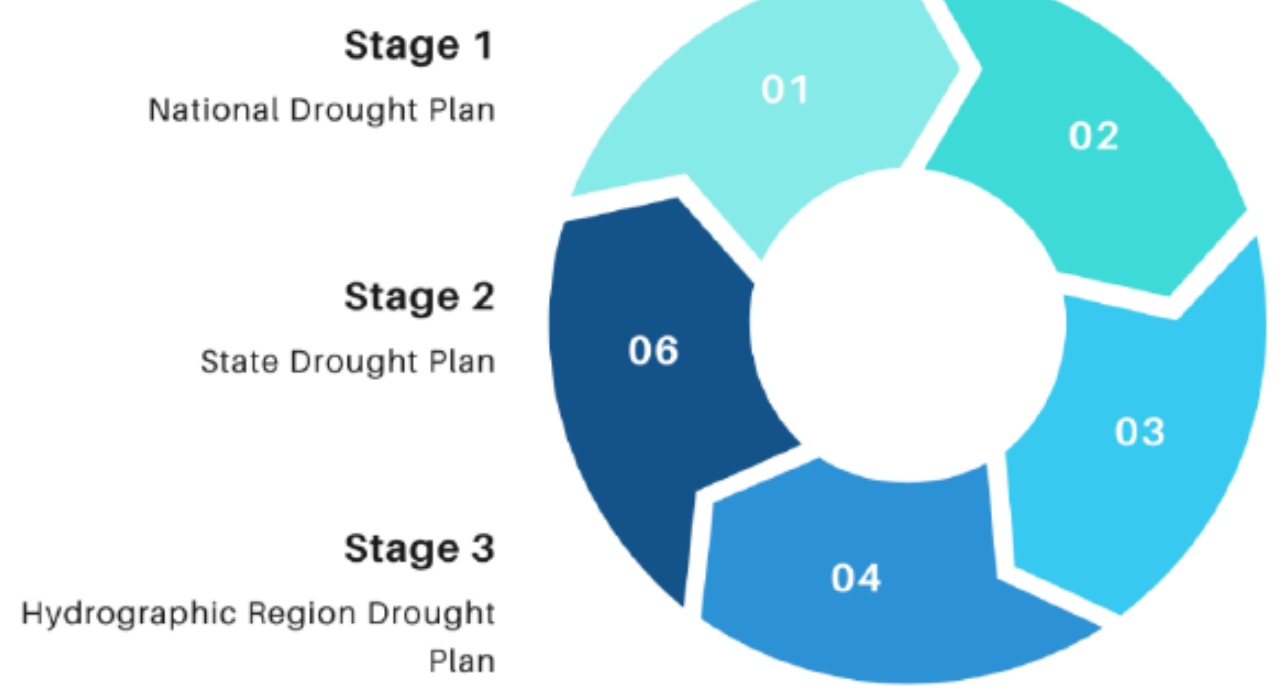

\section{Stage 4}

Hydrossystem Drought Plan

\section{Stage 5}

Urban Water Utilities Drought Plan

\section{Stage 6}

Farm Drought Plan

\section{Figure 1}



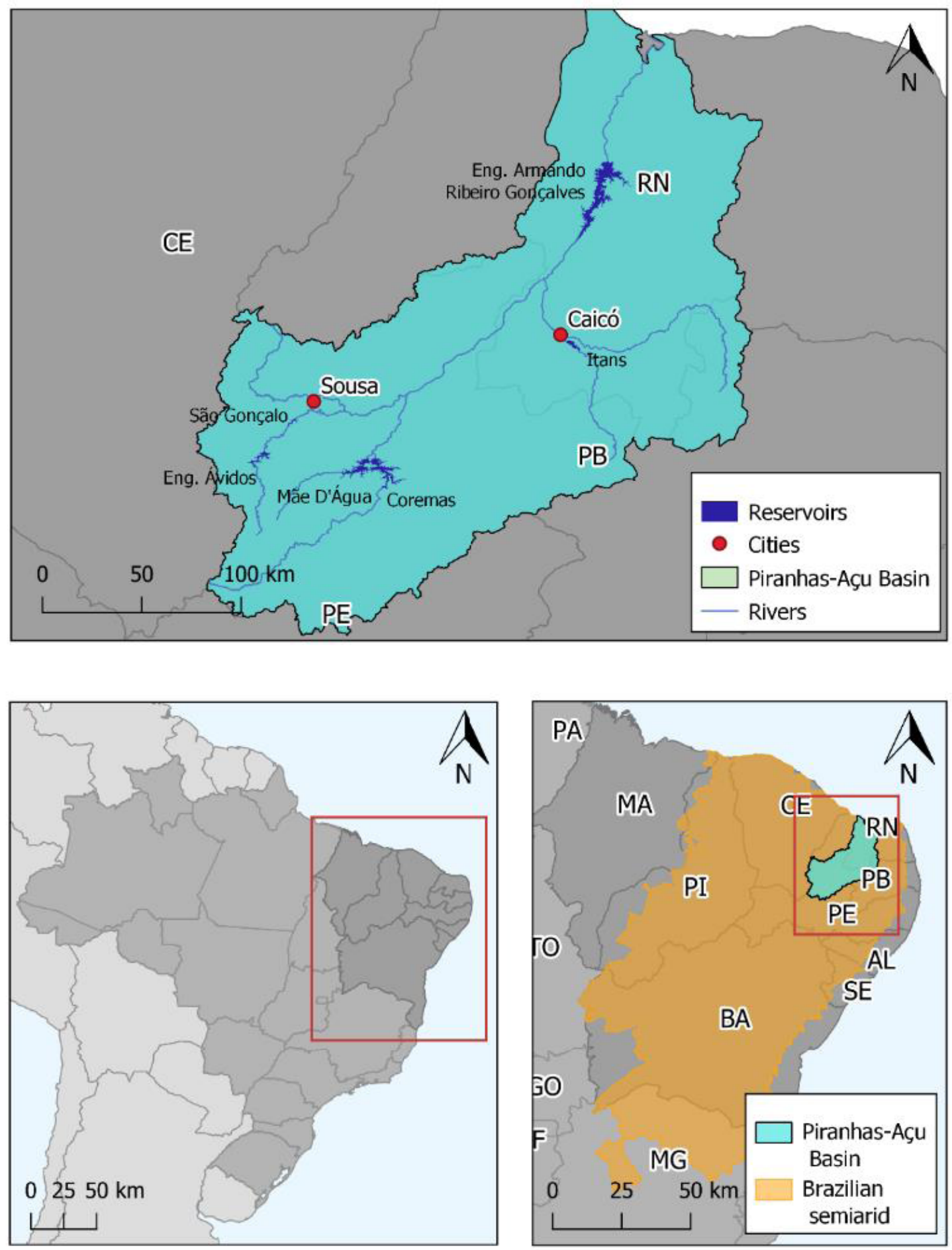

Figure 2

Piranhas-Açu river basin. Location of the hydrosystems and cities where the proposed methodology was implemented. Note: The designations employed and the presentation of the material on this map do not imply the expression of any opinion whatsoever on the part of Research Square concerning the legal 
status of any country, territory, city or area or of its authorities, or concerning the delimitation of its frontiers or boundaries. This map has been provided by the authors.

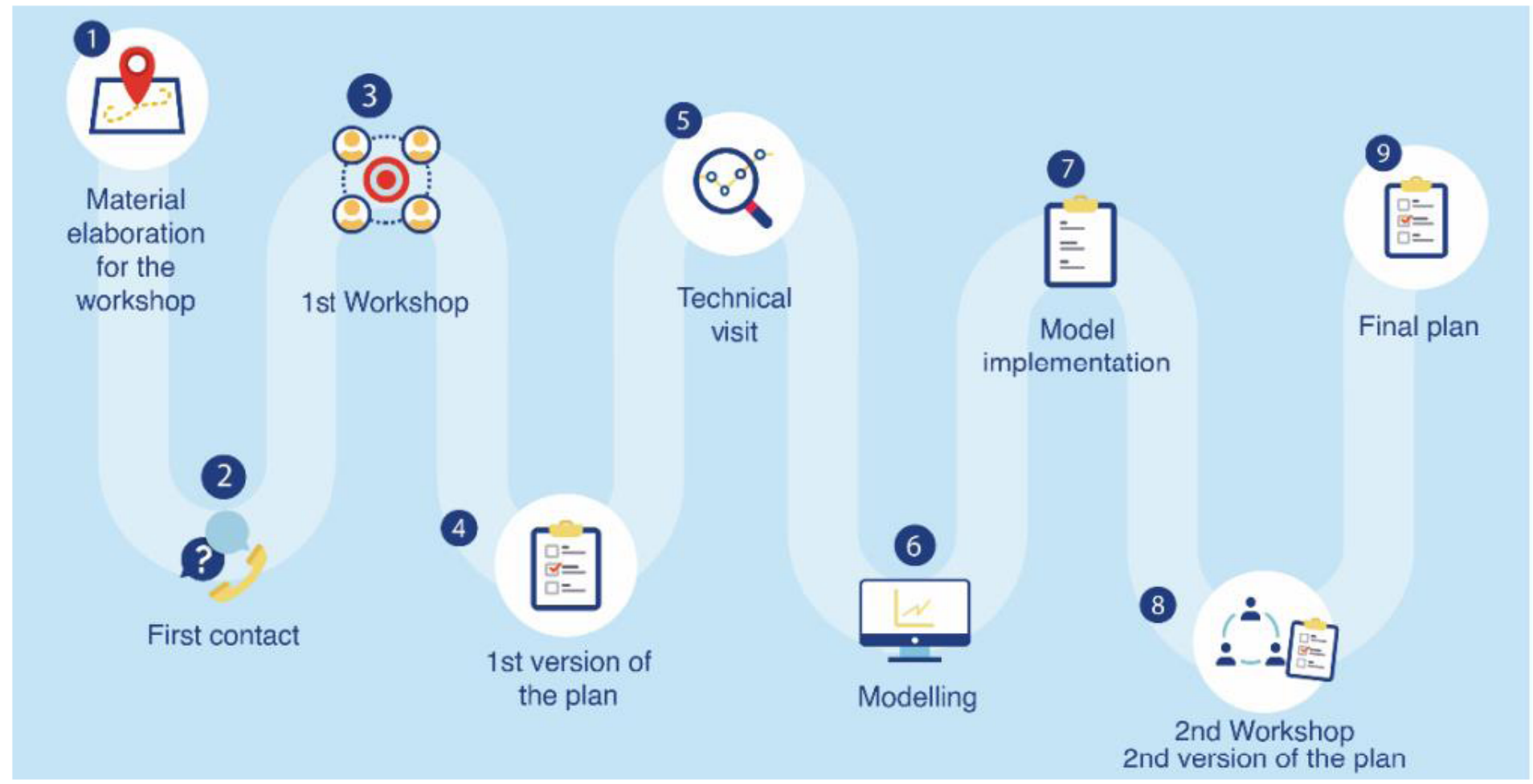

\section{Figure 3}

Drought preparedness plan elaboration methodology 


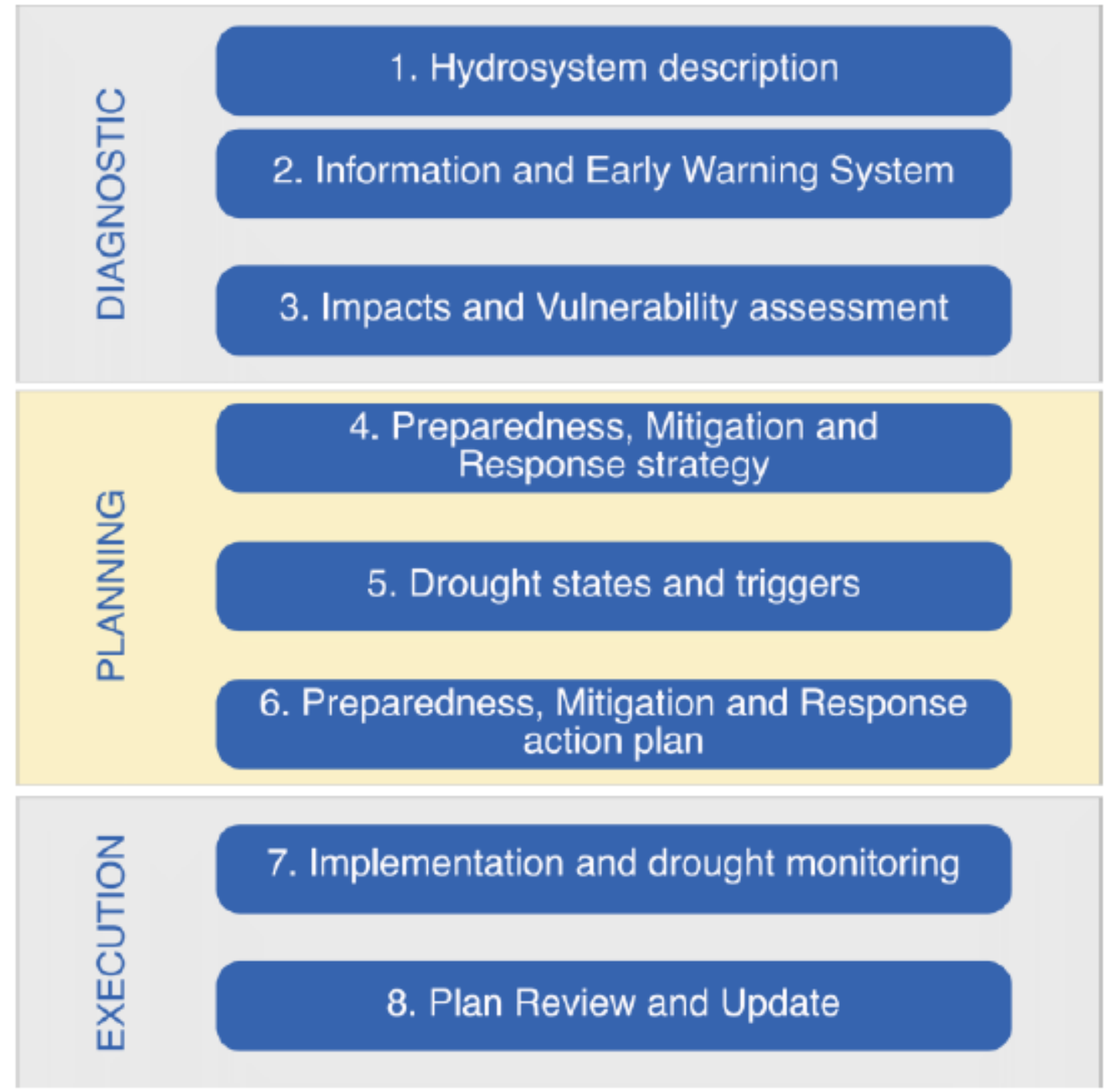

Figure 4

Methodological steps for the elaboration of an Urban Drought Preparedness Plan. 


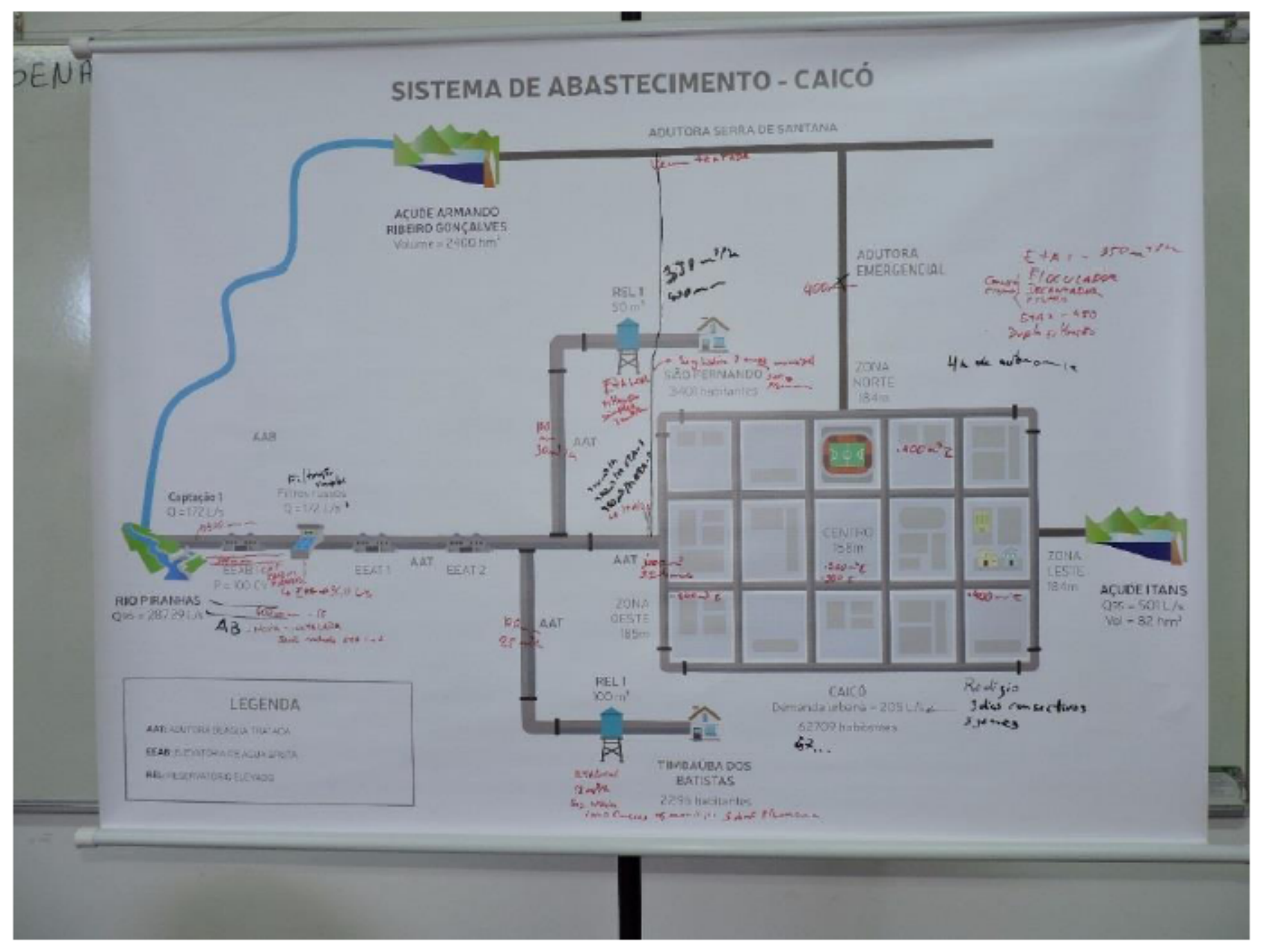

\section{Figure 5}

Updated infographic taken to the Workshop at Caicó City
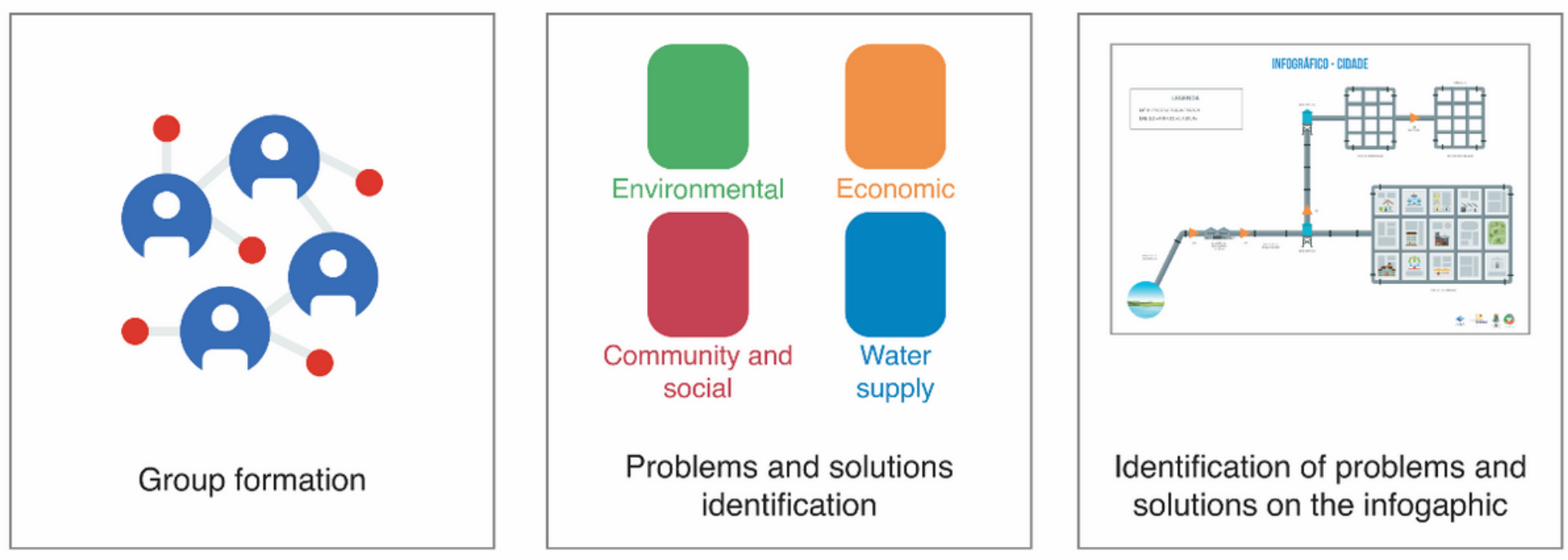

\section{Figure 6}




\section{Workshop methodology steps}
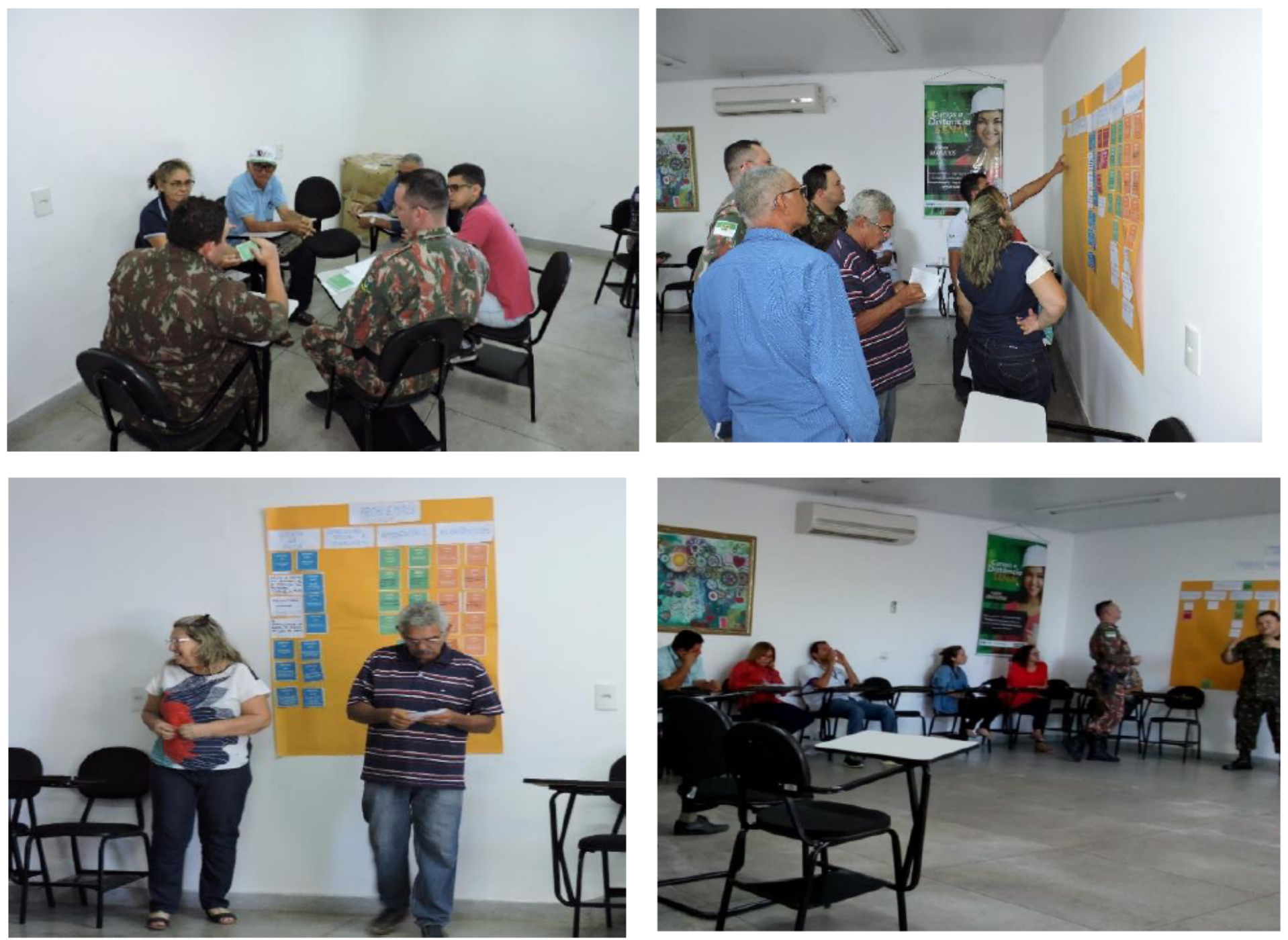

Figure 7

Group discussion and presentation of the groups on the supply problems of the city of Caicó 


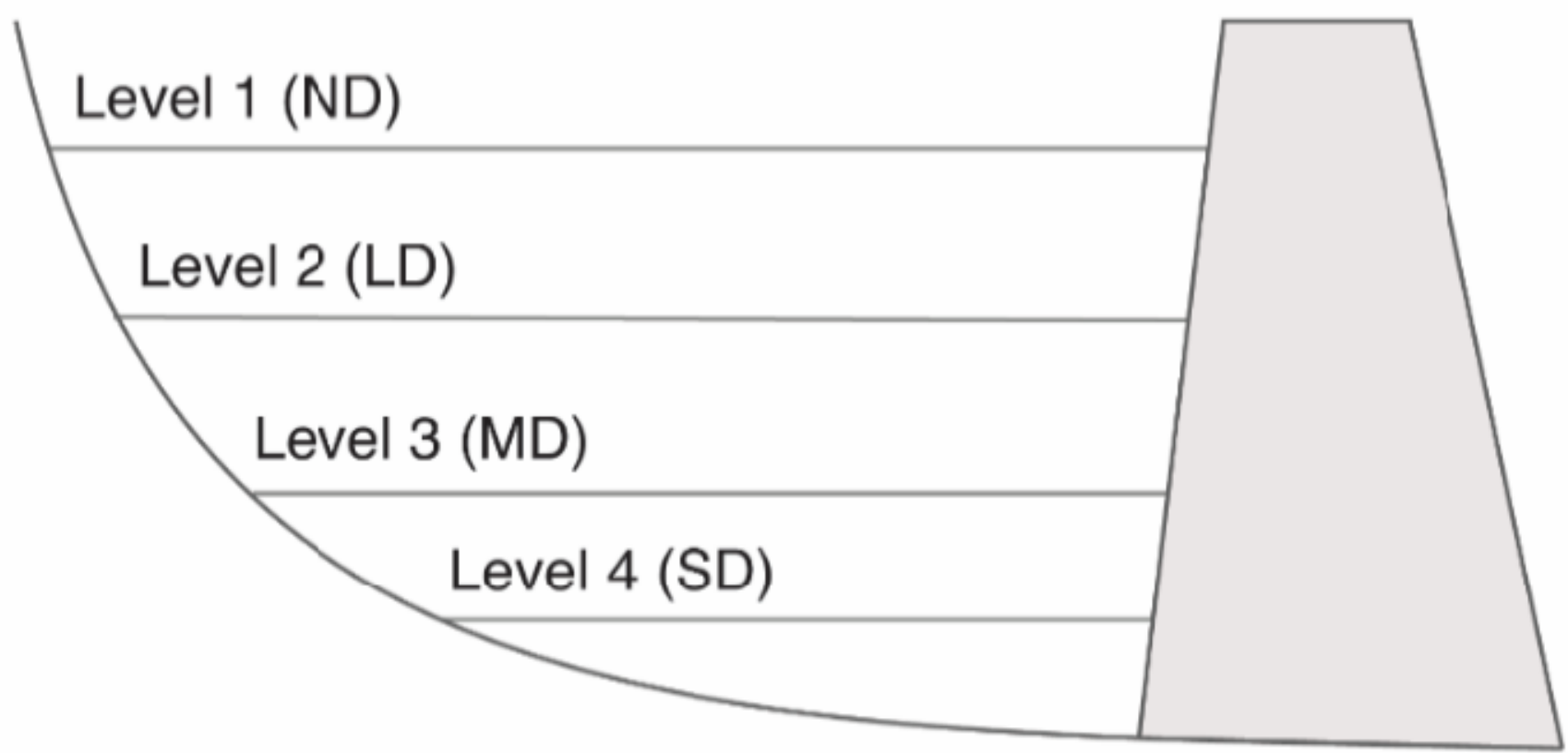

Figure 8

Reservoir zones according to the states of drought

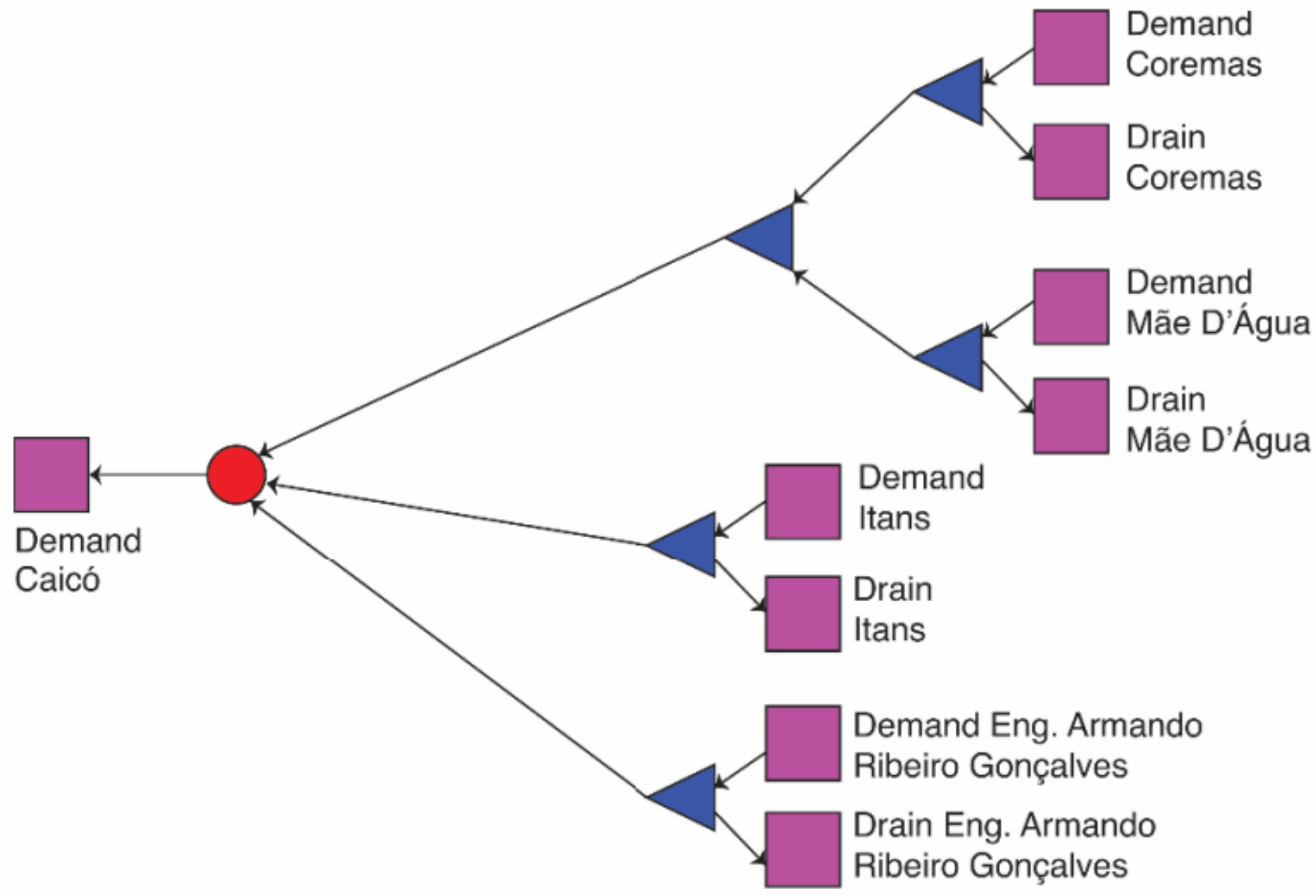

Figure 9 
Scheme of sources of supply used to simulate the supply of the city of Caicó

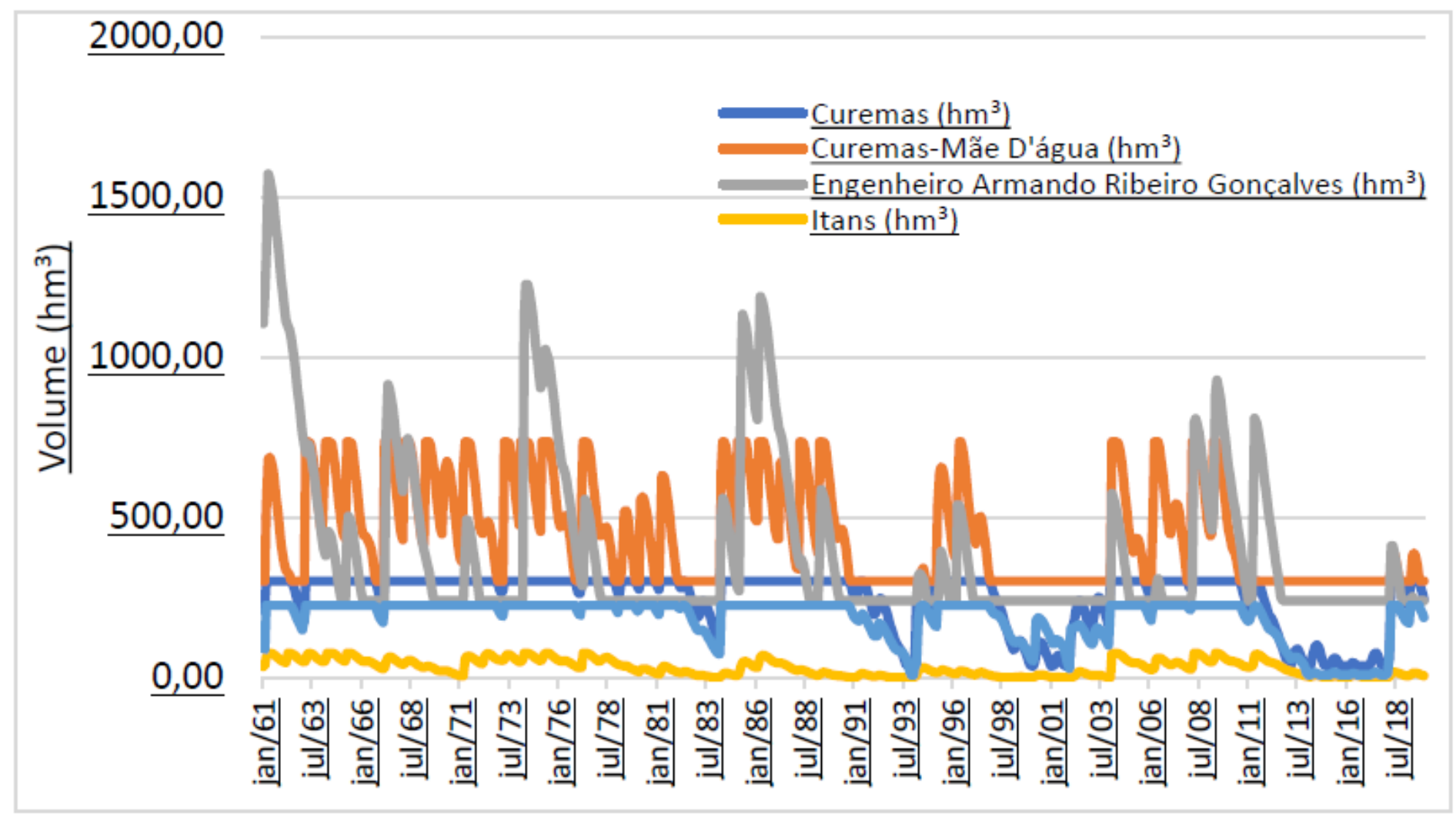

Figure 10

Volumes of Itans reservoirs, Engineer Armando Ribeiro Gonçalves, Curema, Mãe D'água and Curema-Mãe D'água system for the period from 1961 to 2019

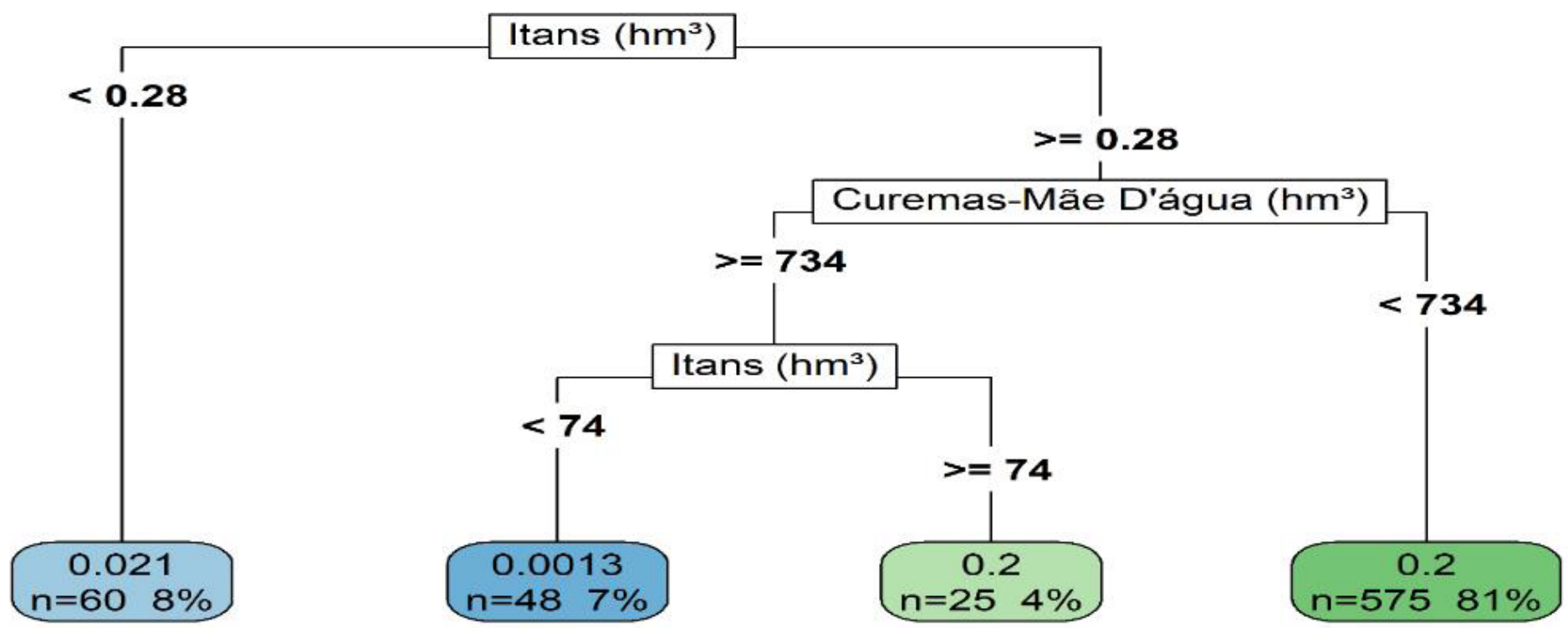

Figure 11 
Decision tree for when withdrawal occurs in the Itans reservoir.

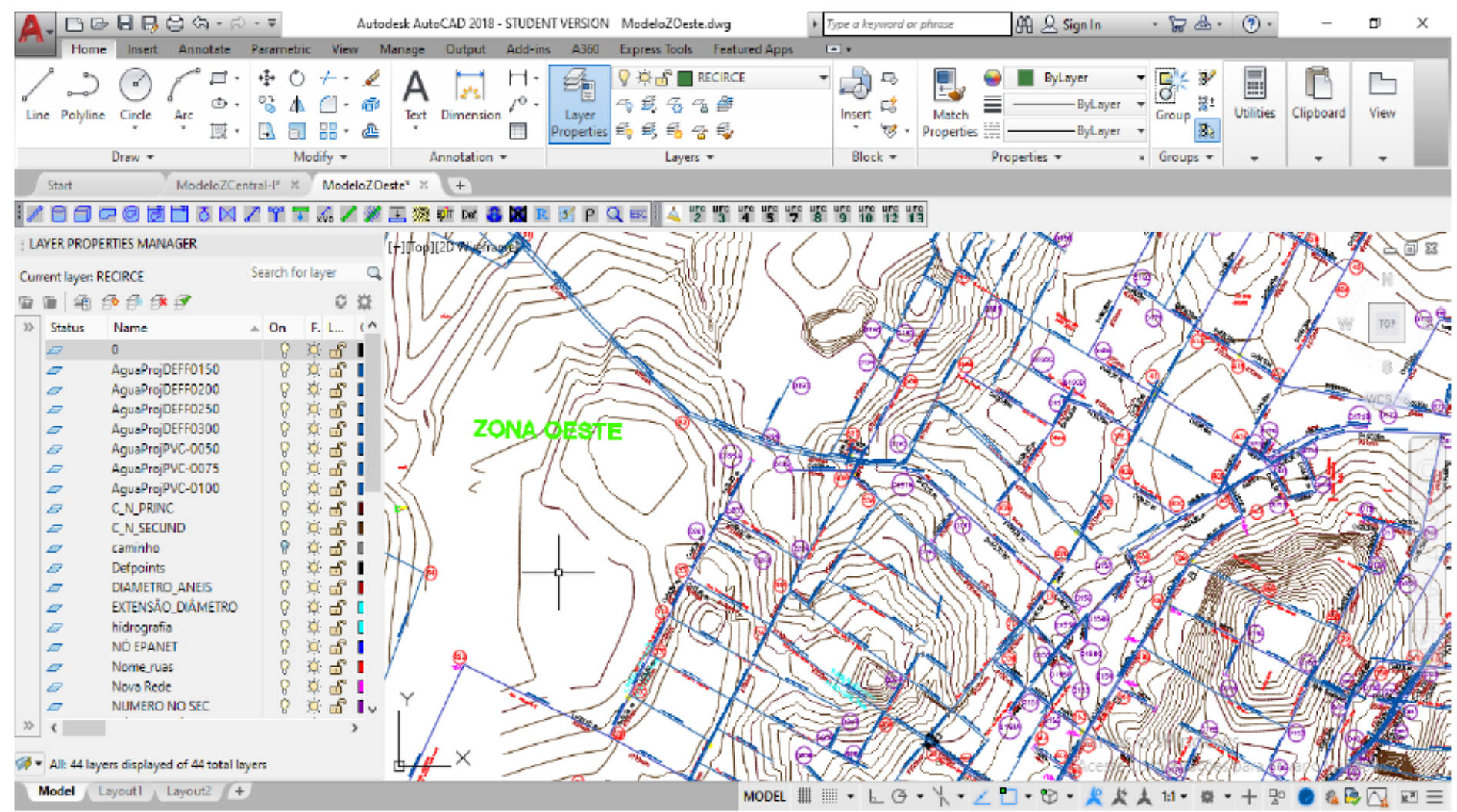

Figure 12

Caicó water network. UFC2 graphic design environment implemented in an AutoCAD interface 